\title{
EVALUATION OF THE IMPACT OF TRACTOR FIELD WORKS ON CHANGES IN SELECTED ELEMENTS OF ENGINE OILS
}

\author{
Wojciech Gołębiowski ${ }^{\mathrm{a}}$, Grzegorz Zając ${ }^{\mathrm{b} *}$, Branislav Sarkan ${ }^{\mathrm{c}}$
}

a Department of Power Engineering and Transportation, University of Life Sciences in Lublin, ul. Głęboka 28, 20-612 Lublin, Poland; e-mail: wojciech.golebiowski@up.lublin.pl ORCID 00000002-4170-1351

b Department of Power Engineering and Transportation, University of Life Sciences in Lublin, ul. Głęboka 28, 20-612 Lublin, Poland; e-mail: grzegorz.zajac@up.lublin.pl ORCID 0000-00029025-4551

c Faculty of Operation and Economics of Transport and Communications, University of Zilina, Univerzitna 1, 01026 Zilina, Slovakia; e-mail: branislav.sarkan@fpedas.uniza.sk ORCID 00000002-5036-9223

*Corresponding author: e-mail: grzegorz.zajac@up.lublin.pl

\begin{tabular}{|c|c|}
\hline ARTICLE INFO & ABSTRACT \\
\hline $\begin{array}{l}\text { Article history: } \\
\text { Received: November } 2021 \\
\text { Received in the revised form: } \\
\text { December } 2021 \\
\text { Accepted: January } 2022 \\
\text { Keywords: } \\
\text { engine oil, } \\
\text { degradation, } \\
\text { farm tractor, } \\
\text { agricultural machine, } \\
\text { operation wear }\end{array}$ & $\begin{array}{l}\text { Tractors are used for various types of field work, as well as for transport } \\
\text { on public roads, in difficult and changing environmental conditions. } \\
\text { The main goal of the study was to analyze the changes of trace elements } \\
\text { in engine oil during various field works. For this purpose, engine oils } \\
\text { from two tractors were selected for the study. These tractors were cou- } \\
\text { pled with: a cultivator, a reversible plow, a tillage-sowing unit, and } \\
\text { a trailer. The samples were taken at the beginning and after the field } \\
\text { work with a given unit was completed. The instrumental chemical anal- } \\
\text { ysis method HDXRF was used to determine changes in the content of } \\
\text { the trace elements: } \mathrm{Cr} \text {, } \mathrm{Cu}, \mathrm{Fe}, \mathrm{Pb}, \mathrm{Ni}, \mathrm{Ca}, \mathrm{P}, \mathrm{Zn} \text {, and Mo in the engine } \\
\text { oil. The comparison of oil from tractors coupled with various agricul- } \\
\text { tural machines allowed the conclusion that the distribution of the con- } \\
\text { sumption of tested metals, as well as the concentrations of individual } \\
\text { elements, differed significantly depending on the coupled machine. The } \\
\text { research showed that agricultural treatments with a cultivator caused } \\
\text { the highest percentage of wear-induced changes in the content of metal } \\
\text { elements such as Cr, Cu, and } \mathrm{Pb} \text {. On the other hand, the operation of } \\
\text { a tractor coupled with a tillage-sowing unit resulted in the vehicle's } \\
\text { accelerated wear. }\end{array}$ \\
\hline
\end{tabular}

\section{Introduction}

Tractors are used for various types of field work, as well as for transport on public roads, in difficult and changing environmental conditions. Wear and tear is an inherent phenomenon in the process of using all machines and devices, including tractors. In the case of tractors, seasonal tasks (plowing, sowing, harvesting, etc.) require particular attention to proper maintenance as the agricultural production process cannot be stopped without irreversible losses (Tomczyk and Kowalczyk, 2016; Mattetti et al., 2021). Quick damage detection allows 
for high availability of the equipment, reduces repair costs, and the duration of possible downtime (Sejkorová, 2015a; Agocs et al., 2021).

One of the most important elements of a tractor is the engine, which is mainly at risk due to the wear of the surfaces of its components in long-term operation. Testing the concentration of various metals in engine oil and knowing their limit values is an effective and practical way of monitoring engine wear, as it often provides early warning on possible component failure (Holloway, 2007; Sejkorová, 2015b; Förster et al., 2019; Hönig et al., 2020). The content of elements in the engine oil depends mainly on the intensity of wear processes, and to a small extent also on contact with fuel or cooling liquid. Typical wear products are elements used in the construction of engine subassemblies, including $\mathrm{Fe}, \mathrm{Cu}, \mathrm{Sn}, \mathrm{Pb}, \mathrm{Ni}, \mathrm{Cr}$, and Al. On other hand, the additives to the engine oil enhancing its basic functions are reduced, which could contribute to accelerated wear of the elements. Monitoring the level of the elements: $\mathrm{Ca}, \mathrm{K}, \mathrm{Na}, \mathrm{B}, \mathrm{Si}, \mathrm{Zn}, \mathrm{P}$ and $\mathrm{Sb}$ in the oil, which is usually associated with the applied additives and/or impurities reaching the oil during wear, allows to determine the rate of oil degradation (Hurtová and Sejkorová, 2016; Chmielewski, 2017; Grimmig et al., 2021).

According to (Napiórkowski and Gonera, 2020) the most common engine failures in tractors are related to the fuel system and turbocharger failures. On the other hand, (Gołębiowski and Zając, 2020) pointed to the problem of fuel system failures and their effects, i.e., fuel leakage into the engine oil, which results in a significant reduction in its viscosity and a lower oil flash point temperature. However, in the case of turbochargers, failures are most often related to the abrasive wear of the bushings and the turbocharger shaft (Kaszkowiak et al., 2015). In turn, the most common causes of turbocharger damage include: contamination in the intake air (dirt, dust, sand, etc.), contamination in the exhaust gas (extraneous matter from the fuel tank, valve splinters, etc.), contamination of oil, too low oil level, or carbon sludge formed as a result of too high exhaust gas temperature (Lotko et al., 2015; Hurtová, 2020).

The main goal of the study was to analyze the changes of trace elements in engine oil during various field works. Elements derived from the wear processes of the working parts of the internal combustion engine were analyzed: chromium $(\mathrm{Cr})$, copper $(\mathrm{Cu})$, iron $(\mathrm{Fe})$, lead $(\mathrm{Pb})$, nickel $(\mathrm{Ni})$, those derived from enriching additives as well as those indicating the presence of contaminants in the oil motor: calcium $(\mathrm{Ca})$, phosphorus $(\mathrm{P})$, zinc $(\mathrm{Zn})$, and molybdenum (Mo).

\section{Material and Methods}

\section{Materials}

For this purpose, engine oils from two tractors were selected for the tests: John Deere 8245R and John Deere 6145R (Fig. 1). These tractors were coupled with various agricultural machines. The tractors from which the samples were collected were operated with Shell Rimula R4 L 15W40 ACEA E7, E9 mineral engine oil. Samples were taken at the beginning and after field work using a given machine. Field conditions were variable depending on the prevailing weather conditions and the type of work performed. The working time of agricultural tractors with coupled machines depended on the area intended for a given work. 


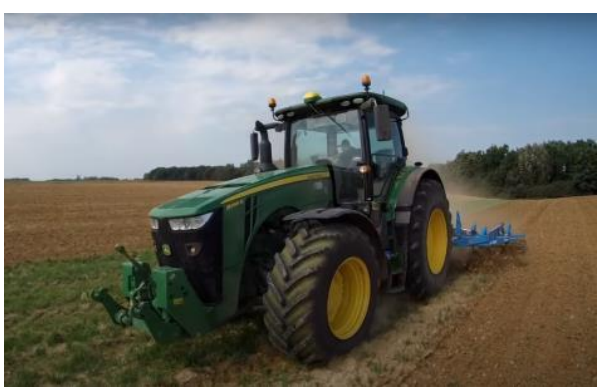

a

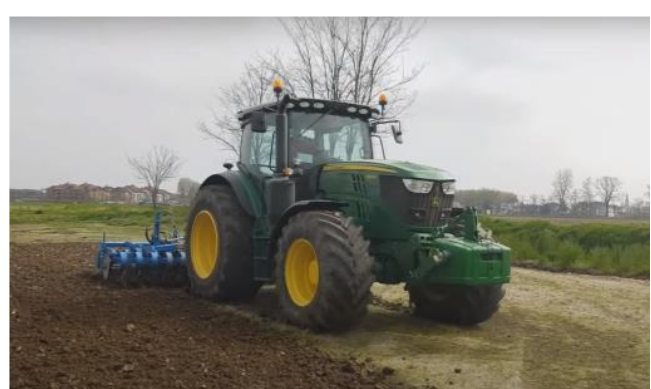

b

Figure 1. Tractors selected for the tests: (a) John Deere 8245R; (b) John Deere 6145R.

The basic parameters of tractors used in the research are presented in Table 1.

Table 1.

Technical characteristics of tractors used during the research.

\begin{tabular}{lcc}
\hline \multicolumn{1}{c}{ Parameter } & John Deere 8245R & John Deere 6145R \\
\hline Cylinders & 6 & 6 \\
Engine capacity $\left(\mathrm{cm}^{3}\right)$ & 9000 & 6788 \\
Rated power $(\mathrm{kW} / \mathrm{hp})$ & $180 / 245$ & $107 / 145$ \\
Max power $(\mathrm{kW} / \mathrm{hp})$ & $198 / 270$ & $135 / 171$ \\
Max torque $(\mathrm{N} \cdot \mathrm{m})$ & 1085 & 677 \\
Fuel tank $\left(\mathrm{dm}^{3}\right)$ & 681 & 312 \\
Oil change intervals $(\mathrm{h})$ & 500 & 500 \\
\hline
\end{tabular}

Table 2 presents information on machines coupled with the tested tractors.

Table 2.

Agricultural machines coupled with the analyzed farm tractors

\begin{tabular}{ll}
\hline Tractor model & Agricultural machine \\
\hline John Deere 8245R & $\begin{array}{l}\text { cultivator [Vaderstad Cultus] } \\
\text { reversible plow [Overum Xcelsior DX-H] }\end{array}$ \\
\hline John Deere 6145R & $\begin{array}{l}\text { tillage-sowing unit [Kuhn Premia and Kuhn HR] } \\
\text { agricultural trailer [Metaltech DB12000] }\end{array}$ \\
\hline
\end{tabular}

The Vaderstad Cultus cultivator allows for simultaneous cultivation of topsoil and mixing of crop residues. The machine can operate at a working depth of up to $25 \mathrm{~cm}$, which allows loosening of the subsoil to improve soil breathability and water percolation. The cultivator's working width is $3 \mathrm{~m}$ and its weight is $2,100 \mathrm{~kg}$. The tillage roller mixes and crushes harvest residues. The shaft has an adjustable working depth, regulated continuously by a hydraulic cylinder. The power demand during cultivation ranges between 120 and $160 \mathrm{HP}$, and the capacity between 2 and $3 \mathrm{ha} / \mathrm{h}$.

Overum Xcelsior DX-H reversible plow with hydraulic protection is designed for plowing on heavy soils. The working width is adjustable and ranges from 2 to $2.5 \mathrm{~m}$. The plow 
consists of five elements, spaced every $1 \mathrm{~m}$, and the clearance under the frame is $75 \mathrm{~cm}$. The approximate weight is $1,840 \mathrm{~kg}$, while the power demand ranges from 150 to $180 \mathrm{HP}$.

The tillage-sowing unit consisting of a Kuhn Premia seeder and a Kuhn HR rotary harrow is used for crushing and loosening of the soil, immediately followed by sowing. Its working pass is $3 \mathrm{~m}$. The harrow can operate in all conditions; its minimum power requirement is $90 \mathrm{KM}$, while its weight with the Steelliner roller is $1730 \mathrm{~kg}$. On the other hand, the $575 \mathrm{~kg}$ seeder is equipped with a mechanical seeding drive, consisting of the HELICA seeding unit with spiral grooves $\left(1.5\right.$ to $\left.450 \mathrm{~kg} \cdot \mathrm{ha}^{-1}\right)$. The dimensions of the loading box are $301 \times 51 \mathrm{~cm}$, and its capacity is 480 liters. The seeds or grains are sown in 20 rows spaced at $15 \mathrm{~cm}$.

The Metaltech DB12000 agricultural trailer is used to transport agricultural loads. The trailer has 2 axles and is equipped with parabolic springs. The length of the load box is $4500 \mathrm{~mm}$, while the total length is $7020 \mathrm{~mm}$. The width of the load box is $2420 \mathrm{~mm}$, and the total width of the trailer is $2550 \mathrm{~mm}$. The capacity of the load box is $15.2 \mathrm{~m}^{3}$ and the technical load capacity is $12,000 \mathrm{~kg}$. The unladen weight of the trailer is $3965 \mathrm{~kg}$. The minimum power of the coupled tractor is $89 \mathrm{HP}$.

\section{Material and Methods}

Metal content analysis was carried out using the multi-element HDMaxine analyzer by XOS to determine trace elements in liquid samples on a hydrocarbon matrix, using highdefinition X-ray fluorescence (HDXRF). The device simultaneously determined the content of $\mathrm{Cd}, \mathrm{Pb}, \mathrm{Sn}, \mathrm{Zn}, \mathrm{Cu}, \mathrm{Ni}, \mathrm{Fe}, \mathrm{Mn}$ and $\mathrm{Mo}$ in the ranges corresponding to the concentrations of these elements present in engine oils. A double curved crystal (DCC) was used to monochromatize and focus the X-ray beam. Monochrome excitation effectively reduced background scattering, which increased accuracy and enabled to precisely capture X-rays from various elements and focus them into a single, concentrated beam.

The test was carried out by placing $1 \mathrm{ml}$ of oil in a measuring cup using an automatic pipette. Before measurements were performed, the device was calibrated with the use of appropriate standards. The tests were repeated in triplicate, and the mean values were given as the results.

The obtained results were statistically analyzed using the STATISTICA 13 software. One-way analysis of variance (ANOVA) was used to assess the effect of the specific field work on the amount of obtained elements in the engine oil, and statistical significance was determined at 0.05 (any result below this value was considered statistically significant). Value $p<0.01$ was considered highly statistically significant, as a measure of chance probability of the observed differences.

\section{Results and Discussion}

The results of the research on changes in the content of elements during the working load are presented in Figure 2.

It was observed that the content of all the wear elements in the engine oil is traceable. Of all the analyzed elements from wear processes, the concentration of iron $(\mathrm{Fe})$ in the oil was 
the highest. Increased Fe content occurs naturally in oil since this element is the main construction material in the engine (Malinowska, 2014). The highest percentage increase $(115 \%)$ was observed after using a tillage-sowing unit. Percentage changes of $\mathrm{Fe}$ in relation to the field work performed with the other analyzed machines amounted to $46 \%$ for the trailer, $14 \%$ for the reversible plow and $13 \%$ for the cultivator, respectively. At the end of work, the $\mathrm{Fe}$ content was within the range of 10.97-11.81 ppm.

Chromium $(\mathrm{Cr})$ is used in systems operating under difficult conditions due to its high hardness and resistance to corrosion. In the engine, it is used e.g., in the piston rings (Vähäoja et al., 2008; Gołębiowski et al., 2018). The highest increase in the content of this element $(62 \%)$ was found during tractor operation with a cultivator, and the lowest $(3 \%)$ when working with a reversible plow. For the remaining analyzed machines, the increase for the tillagesowing unit and the trailer were $35 \%$ and $14 \%$, respectively. For all the machines analyzed, the chromium content at the end of the field work was in the range of 0.37-0.6 ppm.

The increase in $\mathrm{Cu}$ content could indicate an increase in wear of one of the plain bearings (Hönig et al., 2020). The highest increase in $\mathrm{Cu}$ content was found during work with the cultivator $(150 \%)$. The lowest increase in the content of this element was observed for the operation with a trailer $(42 \%)$. When the tractor was coupled with a reversible plow, the $\mathrm{Cu}$ content increased by $83 \%$, and in the case of a tillage-sowing unit $46 \%$. For all machines analyzed, the $\mathrm{Cu}$ content at the end of the work was in the range of $0.22-0.46 \mathrm{ppm}$.

Lead $(\mathrm{Pb})$ is mainly used as a bearing alloy (Malinowska, 2017). The highest increase in $\mathrm{Pb}(34 \%)$ was observed with the use of a cultivator, as in the case of $\mathrm{Cr}$ and $\mathrm{Cu}$. For the remaining machines, the increase in the content of this element was $13 \%$ for the reversible plow, $6 \%$ for transport with the use of a trailer, and $4 \%$ for the tillage-sowing unit. At the end of the field work, the Fe content was within the range of 0.53-0.70 ppm.

Nickel (Ni) found in oil comes mainly from the crankshaft, rings, or valves (Holloway, 2007). No changes in the concentration of this metal were observed for field work with a reversible plow. The use of the tillage-sowing unit was responsible for the highest increase in the content of this element $(68 \%)$. For the remaining cases analyzed, the changes were similar and amounted to $32 \%$ for the cultivator and $29 \%$ for the trailer. At the end of the field work, the nickel content in all analyzed samples was in the range of $0.15-0.33 \mathrm{ppm}$.

The low content of all abrasive metals indicates good lubricating properties of the oil, and their presence does not indicate any potential damage.

Comparing the results of this study with the results of other authors, it can be concluded that the content of the examined elements is at a similar level. (Zajacc et al., 2015), who tested tractors with different mileages, reported that the Fe content was 16.5-267 ppm, $\mathrm{Cu}$ 5.85-11.75 ppm and $\mathrm{Pb} 1.42-13.7 \mathrm{ppm}$. The analyzes of $\mathrm{Cr}, \mathrm{Ni} \mathrm{Pb}$, Fe by (Gołębiowski et al., 2018; Wolak et al., 2018; Hönig et al., 2020) showed a similar nature of oil changes in the engine with increased mileage.

The content of elements from additives or impurities ( $\mathrm{Ca}, \mathrm{P}, \mathrm{Zn}, \mathrm{Mo})$ in the tested engine oils is shown in Fig. 3. Changes in the concentration of additives or impurities were presented in relation to the field work performed by a given tractor. 
Wojciech Gołębiowski, Grzegorz Zając, Branislav Sarkan
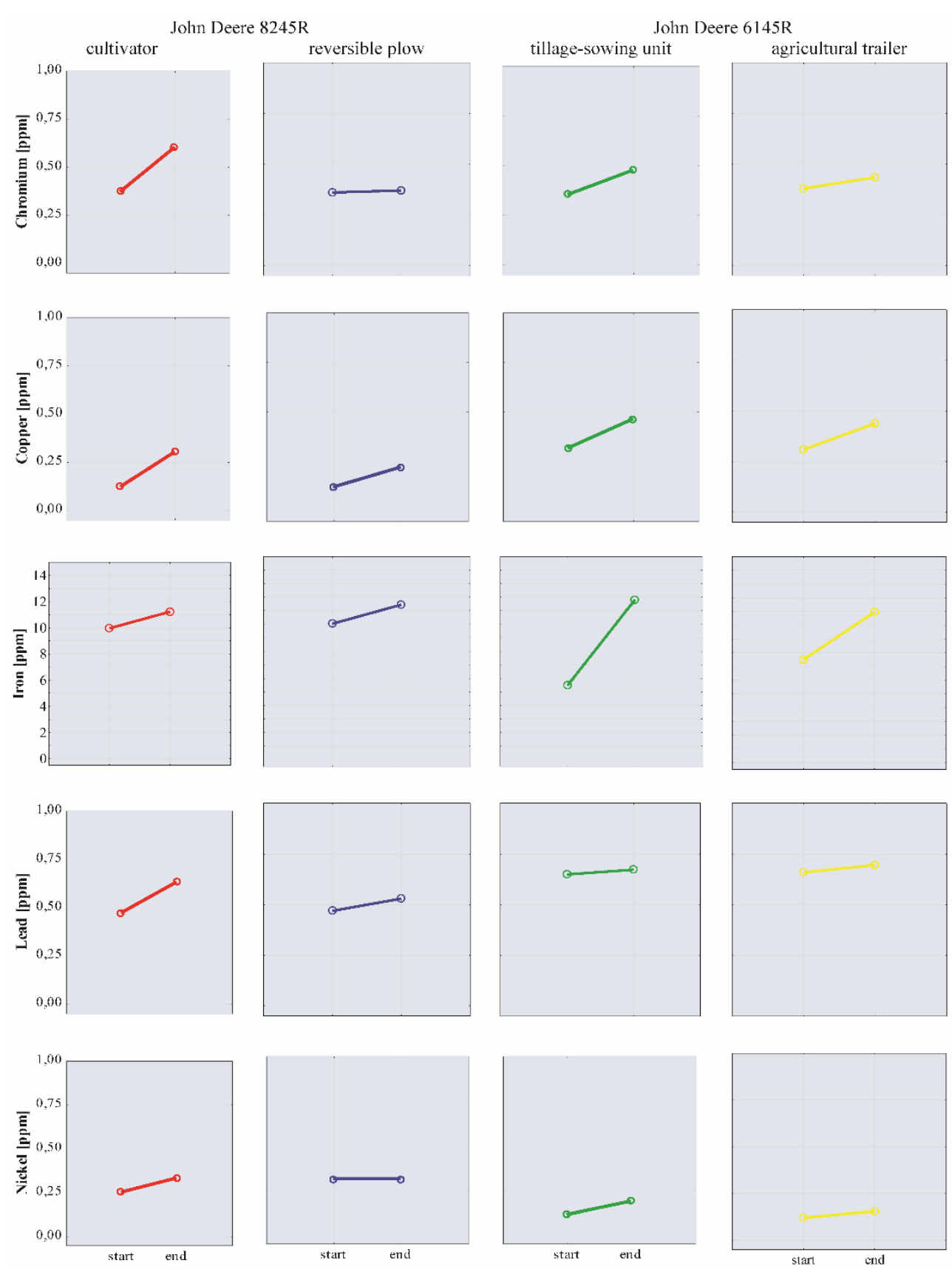

Working cycle

Figure 2. Change in abrasive metal content during working load 
Evaluation of the impact...

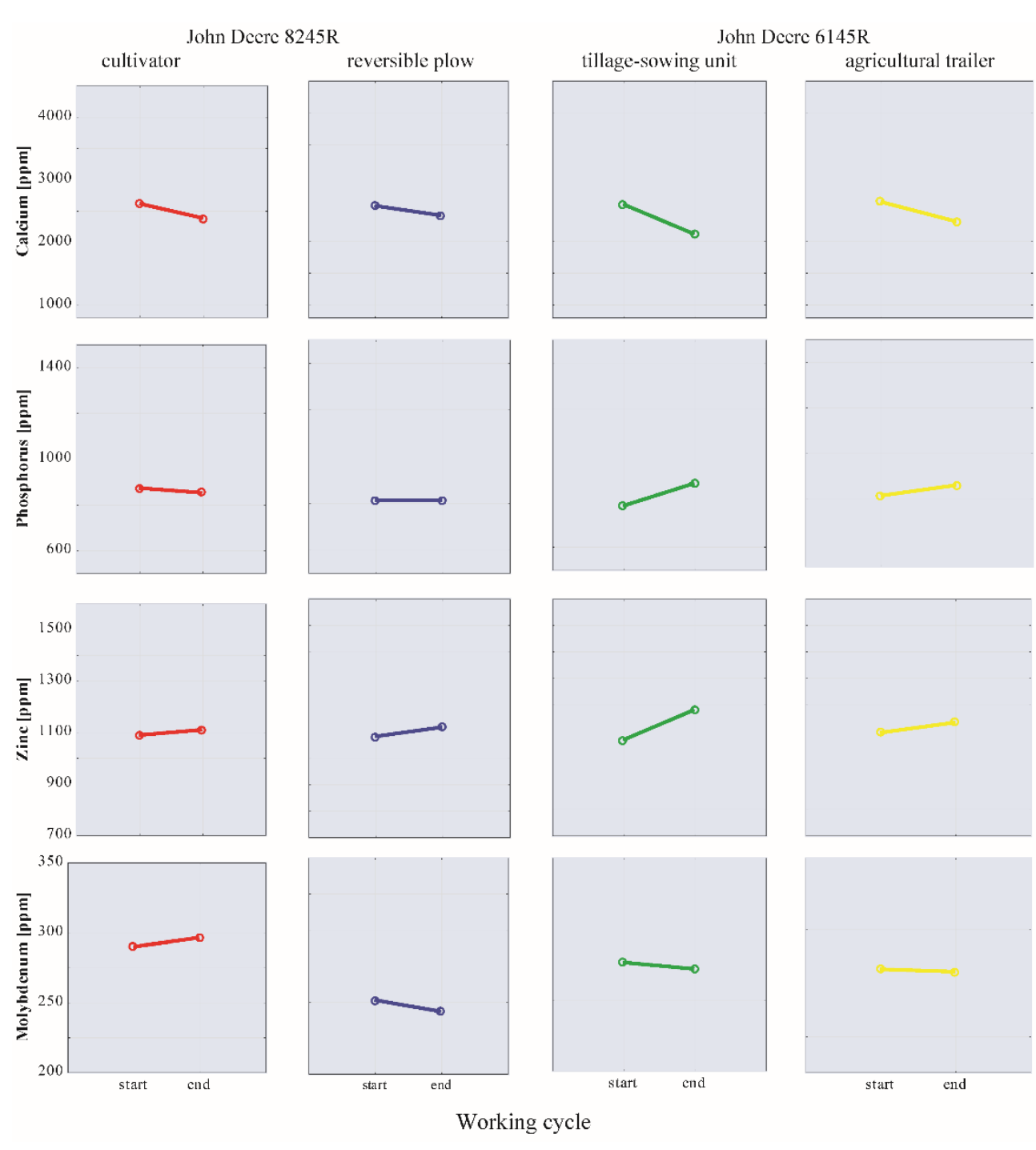

Figure 3. Change in the concentration of additives and impurities during the operation of oils

Cleaning additives are responsible for the presence of $\mathrm{Ca}$ in engine oil (Hönig et al., 2020). In all of the samples tested, a decrease in the content of this element was observable after the field work. The most significant decrease (18\%) can be observed for operation with a tillage-sowing unit. Similarly, for transport work with the use of a trailer, the decrease in Ca was $12 \%$, for field work with the cultivator $9 \%$, and for the plow $6 \%$. The Ca content in all analyzed machines at the end of their operation was in the range of 2097-2390 ppm. 
The most commonly used engine oil additives are ZnDDP zinc dialkylphosphates. They are mainly used for their antioxidant and anti-wear properties. ZnDDP complexes are produced by the reaction of alcohols, phosphorus pentasulfide and zinc salts. Zinc (Zn) can also be used as an alloying element for bearings. On the other hand, the presence of phosphorus (P) can also be the result of oil contamination with coolant or dust (Malinowska, 2017).

In all field works, an increase in $\mathrm{Zn}$ and $\mathrm{P}$ content was observed between the start and the end of the field work (except with the cultivator, for which a $2 \%$ decrease in phosphorus levels was observed). This indicated wear changes and not degradation of additives. In the case of the tillage-sowing unit, the highest increase in $\mathrm{P}$ and $\mathrm{Zn}$ was observed, by $13 \%$ and $11 \%$, respectively. No changes in $\mathrm{P}$ concentration were observed when working with a reversible plow, while the $\mathrm{Zn}$ content increased by $3 \%$. Tractor operation with a trailer led to changes in P levels by $6 \%$ and $\mathrm{Zn}$ by $4 \%$. In all machines analyzed, the $\mathrm{Zn}$ content at the end of operation ranged between $1108-2390 \mathrm{ppm}$, while the $\mathrm{P}$ content ranged between 809-874 ppm.

Molybdenum (Mo) is found in piston rings and bearings, as well as anti-wear (AW) additives (Malinowska, 2014). In all field works performed, excluding work with the cultivator, the Mo content decreased by approximately 1-3\%. The Mo content increase for operation with a cultivator was $2 \%$. For all machines analyzed, the molybdenum content at the end of the field work was in the range of 243-296 ppm.

Analysis shows that the elements content of the examined elements increased with the time of oil use, which could indicate the wear of individual components of the engine. There were slight differences in the nature of this wear according to individual field work. In the previous work of (Gołębiowski and Zając, 2020) the results for P, Zn and Ca showed a similar nature of the changes, which qualitatively corresponds to the results of this study.

Tables 3 and 4 present the results of the statistical analysis of the obtained results.

Table 3.

Summary of averaged changes in the concentrations of elements from wear processes in the engine oil analyzed with a Maxine XOS HD analyzer.

\begin{tabular}{|c|c|c|c|c|c|c|}
\hline \multirow[b]{2}{*}{ Elements } & & & \multicolumn{4}{|c|}{ Agricultural machine } \\
\hline & & & cultivator & $\begin{array}{c}\text { reversible } \\
\text { plow }\end{array}$ & $\begin{array}{c}\text { tillage-so- } \\
\text { wing unit }\end{array}$ & trailer \\
\hline \multirow{3}{*}{$\mathrm{Cr}(\mathrm{ppm}) \pm \mathrm{SD}$} & working & start & $0.37 \pm 0.00$ & $0.36 \pm 0.01$ & $0.35 \pm 0.01$ & $0.38 \pm 0.02$ \\
\hline & cycle & end & $0.6 \pm 0.10$ & $0.37 \pm 0.01$ & $0.47 \pm 0.04$ & $0.43 \pm 0.01$ \\
\hline & \multicolumn{2}{|c|}{$p$-value } & 0.05 & 0.52 & 0.01 & 0.01 \\
\hline \multirow{3}{*}{$\mathrm{Cu}(\mathrm{ppm}) \pm \mathrm{SD}$} & working & start & $0.12 \pm 0.01$ & $0.12 \pm 0.00$ & $0.32 \pm 0.03$ & $0.31 \pm 0.04$ \\
\hline & cycle & end & $0.3 \pm 0.01$ & $0.22 \pm 0.01$ & $0.46 \pm 0.02$ & $0.44 \pm 0.09$ \\
\hline & \multicolumn{2}{|c|}{$p$-value } & 0.01 & 0.01 & 0.01 & 0.10 \\
\hline \multirow{3}{*}{$\mathrm{Fe}(\mathrm{ppm}) \pm \mathrm{SD}$} & working & start & $9.96 \pm 0.28$ & $10.04 \pm 0.18$ & $5.49 \pm 0.09$ & $7.50 \pm 0.26$ \\
\hline & cycle & end & $11.23 \pm 0.07$ & $11.45 \pm 0.18$ & $11.81 \pm 0.14$ & $10.97 \pm 0.19$ \\
\hline & \multicolumn{2}{|c|}{$p$-value } & 0.01 & 0.01 & 0.01 & 0.01 \\
\hline \multirow{3}{*}{$\mathrm{Pb}(\mathrm{ppm}) \pm \mathrm{SD}$} & working & start & $0.47 \pm 0.01$ & $0.47 \pm 0.01$ & $0.65 \pm 0.02$ & $0.66 \pm 0.03$ \\
\hline & cycle & end & $0.63 \pm 0.03$ & $0.53 \pm 0.03$ & $0.67 \pm 0.03$ & $0.70 \pm 0.01$ \\
\hline & \multicolumn{2}{|c|}{$p$-value } & 0.01 & 0.05 & 0.35 & 0.21 \\
\hline \multirow{3}{*}{$\mathrm{Ni}(\mathrm{ppm}) \pm \mathrm{SD}$} & working & start & $0.25 \pm 0.04$ & $0.31 \pm 0.03$ & $0.11 \pm 0.00$ & $0.12 \pm 0.00$ \\
\hline & cycle & end & $0.33 \pm 0.01$ & $0.31 \pm 0.01$ & $0.18 \pm 0.00$ & $0.15 \pm 0.02$ \\
\hline & \multicolumn{2}{|c|}{$p$-value } & 0.05 & 0.86 & 0.01 & 0.07 \\
\hline
\end{tabular}

SD - Standard deviation 
Evaluation of the impact...

Table 4

Summary of averaged changes in the concentrations of elements from wear processes in the engine oil analyzed with a Maxine XOS HD analyzer.

\begin{tabular}{|c|c|c|c|c|c|c|}
\hline \multirow[b]{2}{*}{ Elements } & & & \multicolumn{4}{|c|}{ Agricultural machine } \\
\hline & & & cultivator & $\begin{array}{c}\text { reversible } \\
\text { plow }\end{array}$ & $\begin{array}{l}\text { tillage-so- } \\
\text { wing unit }\end{array}$ & trailer \\
\hline \multirow{3}{*}{$\mathrm{Ca}(\mathrm{ppm}) \pm \mathrm{SD}$} & working & start & $2608 \pm 8$ & $2540 \pm 4$ & $2564 \pm 36$ & $2601 \pm 22$ \\
\hline & cycle & end & $2376 \pm 2$ & $2390 \pm 8$ & $2097 \pm 10$ & $2294 \pm 12$ \\
\hline & \multicolumn{2}{|c|}{$p$-value } & 0.01 & 0.01 & 0.01 & 0.01 \\
\hline \multirow{3}{*}{$\mathrm{P}(\mathrm{ppm}) \pm \mathrm{SD}$} & working & start & $871 \pm 20$ & $809 \pm 15$ & $776 \pm 8$ & $810 \pm 18$ \\
\hline & cycle & end & $850 \pm 14$ & $809 \pm 16$ & $874 \pm 19$ & $856 \pm 17$ \\
\hline & \multicolumn{2}{|c|}{$p$-value } & 0.24 & 1.00 & 0.01 & 0.05 \\
\hline \multirow{3}{*}{$\mathrm{Zn}(\mathrm{ppm}) \pm \mathrm{SD}$} & working & start & $1087 \pm 13$ & $1078 \pm 4$ & $1062 \pm 1$ & $1089 \pm 2$ \\
\hline & cycle & end & $1108 \pm 2$ & $1112 \pm 3$ & $1176 \pm 1$ & $1128 \pm 1$ \\
\hline & \multicolumn{2}{|c|}{$p$-value } & 0.06 & 0.01 & 0.01 & 0.01 \\
\hline \multirow{3}{*}{ 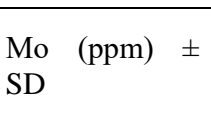 } & working & start & $289 \pm 5$ & $251 \pm 20$ & $276 \pm 12$ & $272 \pm 6$ \\
\hline & cycle & end & $296 \pm 5$ & $243 \pm 8$ & $271 \pm 2$ & $270 \pm 4$ \\
\hline & \multicolumn{2}{|c|}{$p$-value } & 0.24 & 0.56 & 0.59 & 0.72 \\
\hline
\end{tabular}

SD - Standard deviation

During field work with the cultivator, highly significant differences in changes in the concentration of $\mathrm{Cu}, \mathrm{Fe}, \mathrm{Pb}$ and $\mathrm{Ca}$ were observed, as well as statistically significant differences in the concentration of $\mathrm{Ni}$ and $\mathrm{Cr}$. No statistical differences were observed for $\mathrm{P}, \mathrm{Zn}$, and Mo. Field work with the reversible plow showed highly statistically significant differences in changes in the content of $\mathrm{Cu}, \mathrm{Fe}, \mathrm{Ca}$, and $\mathrm{Zn}$ and statistically significant differences in the concentration of $\mathrm{Pb}$. No statistical differences were observed in the changes in the content of $\mathrm{Cr}, \mathrm{Ni}$, and $\mathrm{Mo}$. In the case of $\mathrm{P}$, the analysis showed that the entire operation cycle did not change the content of this element.

Tractor operation with the tillage-sowing unit showed highly statistically significant differences in the changes in $\mathrm{Cr}, \mathrm{Cu}, \mathrm{Fe}, \mathrm{Ni}, \mathrm{Ca}, \mathrm{P}$, and $\mathrm{Zn}$ content, while no statistically significant differences were observed in the case of $\mathrm{Pb}$ and Mo. Transport work with the trailer showed highly statistically significant differences in changes in $\mathrm{Cu}, \mathrm{Fe}, \mathrm{Ca}$, and $\mathrm{Zn}$ content, and statistically significant differences in the concentration of $\mathrm{Pb}$. No statistically significant differences were observed in the content of $\mathrm{Cu}, \mathrm{Pb}, \mathrm{Ni}$, and $\mathrm{Mo}$.

The calculated value of the standard deviation of the compared distributions did not affect the differences in the arithmetic means. Therefore, it was concluded that the distributions are statistically significantly different from each other. Despite the similarity in terms of quantitative differences with other machines, no statistically significant differences were observed only for $\mathrm{Cu}$ content in tractor operation with the trailer. This is due to the large standard deviation of the obtained results.

\section{Conclusions}

Analysis of changes in the content of elements in engine oil is a potential source of information about the wear process of individual engine components. These changes depend on 
the type of vehicle, the nature of its operation, and the duration of its use. Regular quality control of the engine oil prevents and timely identifies defects in engine components, based on, for example, an increase in certain abrasive metals or dust particles.

Comparison of oils from tractors coupled with various agricultural machines allowed to conclude that, regardless of the type of field work, highly statistically significant differences were observed in the case of changes in the content of iron $(\mathrm{Fe})$ and calcium $(\mathrm{Ca})$. An increase in the content of iron $(\mathrm{Fe})$, copper $(\mathrm{Cu})$ and molybdenum (Mo) was observed, which could indicate the sources of the elements, i.e., the wear of slide bearings, thrust bearings, crankshafts, pistons, connecting rods, and the injection system.

The research showed that field work with the use of a cultivator caused the most significant changes (increase) in the content of elements coming from wear processes, i.e., $\mathrm{Cr}$ $62 \%, \mathrm{Cu}-150 \%$ and $\mathrm{Pb}-34 \%$. Also, field work with the tillage-sowing unit caused the greatest changes in the content of wear-related elements - Fe by $115 \%$ and $\mathrm{Ni}$ by $68 \%$. In both cases, the highest decreases in Ca content (an additive) were also noted. For the tillagesowing unit, the decrease was $18 \%$, and for the cultivator $9 \%$. This allows a conclusion that the operation of the tractor coupled with these machines causes the greatest changes; monitoring the changes in the content of these metals in the engine oil every season is recommended.

The analysis of the levels of wear-related concentrations of chemical elements can only be part of the diagnostics of vehicles. For more detailed information on the sources of pollution, the tests should be extended to include the measurement of the total acid number (TAN), total base number (TBN) and the level of oxidation.

\section{References}

Agocs, A., Nagy, A. L., Tabakov, Z., Perger, J., Rohde-Brandenburger, J., Schandl, M., Besser, C., Dörr, N. (2021). Comprehensive assessment of oil degradation patterns in petrol and diesel engines observed in a field test with passenger cars-Conventional oil analysis and fuel dilution. Tribology International, 161, 107079.

Chmielewski, Z. (2017). Stany niezawodnościowe oleju silnikowego w eksploatacji. Autobusy: technika, eksploatacja, systemy transportowe, 18, 761-764.

Förster, E., Fraenza, C. C., Küstner, J., Anoardo, E., Nirschl, H., Guthausen, G. (2019). Monitoring of engine oil aging by diffusion and low-field nuclear magnetic resonance relaxation. Measurement, 137, 673-682.

Gołębiowski, W., Zając, G., Wolak, A. (2018). Zawartość metali w olejach silnikowych z ciągników rolniczych (Contents of metals in engine oils from agricultural tractors). Przemyst Chemiczny, 97(5), 696-699.

Gołębiowski, W., Zając, G. (2020). Impact assessment of farm tractor engine fuel injector damage on engine oil properties. Agricultural Engineering, 24(2), 65-75.

Grimmig, R., Lindner, S., Gillemot, P., Winkler, M., Witzleben, S. (2021). Analyses of used engine oils via atomic spectroscopy - Influence of sample pre-treatment and machine learning for engine type classification and lifetime assessment. Talanta, 232, 122431.

Holloway, M. (2007). The Oil Analysis Handbook: A Comprehensive Guide to Using and Understanding Oil Analysis. NCH Corporation: Irving, TX, USA.

Hönig, V., Procházka, P., Obergruber, M., Kučerová, V., Mejstř́ik, P., Macků, J., Bouček, J. (2020). Determination of Tractor engine oil change interval based on material properties. Materials, 13(23), 5403. 
Evaluation of the impact...

Hurtová, I. (2020). Hodnocení karbonového znečištění motorových olejů. Perner's Contacts, 15(2), 1652.

Hurtová, I., Sejkorová, M. (2016). Analysis of engine oils using modern methods of tribotechnical diagnostics. Perner's Contacts, 11(4), 47-53.

Kaszkowiak, J., Borowski, S., Dulcet, E., Zastempowski, M. (2015). Analiza uszkodzeń turbosprężarek. Logistyka, 4, 1885-1892.

Lotko, W., Longwic, R., Górski, K., Sander, P., Durczak, T. (2015). Analiza przyczyn uszkodzeń turbosprężarek samochodowych. TTS Technika Transportu Szynowego, 22, 1833-1836.

Malinowska, M. (2014). Analiza zanieczyszczeń oleju silnikowego stosowanego w silniku CegielskiSulzer 3AL25/30. Zeszyty Naukowe Akademii Morskiej w Gdyni, 83, 194-202.

Malinowska, M. (2017). Spectroscopic study and analysis of the content of residue elements in Marinol RG 1240 oil after working in various types of engines. Zeszyty Naukowe Akademii Morskiej w Gdyni, 100, 131-140.

Mattetti, M., Maraldi, M., Lenzini, N., Fiorati, S., Sereni, E., Molari, G. (2021). Outlining the mission profile of agricultural tractors through CAN-BUS data analytics. Computers and Electronics in Agriculture, 184, 106078.

Napiórkowski, J., Gonera, J. (2020). Analysis of failures and reliability model of farm tractors. Agricultural Engineering, 24(2), 89-101.

Sejkorová, M. (2015)a. Possibilities of processing the tribodiagnostic data. Perner's Contacts, 10(4), 93-97.

Sejkorová, M. (2015)b. Tribotechnical diagnostics as a tool for effective management of maintenance. Perner's Contacts, 10(3), 126-136.

Tomczyk, W., Kowalczyk, Z. (2016). The wear processes in the aspect of construction quality and the need to apply agricultural machines servicing. Journal of Research and Applications in Agricultural Engineering, 61(2), 114-119.

Wolak, A., Zając, G., Żółty, M. (2018). Changes of properties of engine oils diluted with diesel oil under real operating conditions. Combustion Engines, 73(2), 34-40.

Vähäoja, P., Välimäki, I., Roppola, K., Kuokkanen, T., Lahdelma, S. (2008). Wear Metal Analysis of Oils. Critical Reviews in Analytical Chemistry, 38(2), 67-83.

Zając, G., Szyszlak-Bargłowicz, J., Słowik, T., Kuranc, A., Kamińska, A. (2015). Designation of Chosen Heavy Metals in Used Engine Oils Using the XRF Method. Polish Journal of Environmental Studies, 24, 2277-2283. 


\section{OCENA WPLYWU WYKONYWANYCH PRAC POLOWYCH CIĄGNIKÓW ROLNICZYCH NA ZMIANY WYBRANYCH PIERWIASTKÓW W OLEJACH SILNIKOWYCH}

Streszczenie. Ciągniki w zależności od potrzeb wykorzystywane są do różnego rodzaju prac polowych, jak i do transportu po drogach publicznych, przy czym użytkowanie to odbywa się w trudnych i zmiennych warunkach środowiskowych. Podstawowym celem pracy była analiza zmian pierwiastków śladowych w oleju silnikowym podczas wykonywania różnych prac polowych. Do badań zostały wytypowany oleje silnikowe pochodzące $\mathrm{z}$ dwóch ciągników. Ciągniki te były zagregowane z: kultywatorem, pługiem obrotowym, zestawem uprawowo-siewnym oraz przyczepą rolniczą. Próbki pobierane były w momencie rozpoczęcia oraz po zakończeniu pracy z daną maszyną. Do określenia zmian zawartości pierwiastków śladowych $\mathrm{Cr}, \mathrm{Cu}, \mathrm{Fe}, \mathrm{Pb}, \mathrm{Ni}, \mathrm{Ca}, \mathrm{P}, \mathrm{Zn}$, Mo w oleju silnikowym zastosowano instrumentalna metode analizy chemicznej HDXRF. Porównanie olejów pochodzących z ciagników zagregowanych z różnymi maszynami rolniczymi pozwoliła stwierdzić, że rozkłady zużycia badanych metali wraz ze stężeniami poszczególnych pierwiastków różniły się znacznie między badanymi maszynami. Na podstawie badań wykazano, że praca polowa z wykorzystaniem kultywatora powodowała największe procentowe zmiany zawartości pierwiastków pochodzących z procesów zużycia takich jak $\mathrm{Cr}, \mathrm{Cu}$ i $\mathrm{Pb}$, natomiast praca ciągnika z zagregowanym zestawem uprawowo-siewnym największe procentowe zmiany zawartości Fe i Ni.

Słowa kluczowe: olej silnikowy, degradacja, ciągnik rolniczy, maszyna rolnicza, zużycie eksploatacyjne 